\title{
The Russo-Finnish Peace
}

From E. M. Salzer, 'What Shaw Thinks of Russia and Finland', Leader, 6 April 1940. In March 1940 Finland sought peace from Russia, after having resisted the Russian invasion launched in November of the previous year. The peace involved the ceding of several Finnish territories to Russia.

Do you agree with those who deplore the Russo-Finnish peace as another Munich, or do you think the Finns had no other choice?

Why ask me? I was explicit enough, I think, when I warned our people that we were backing the wrong horse in the Baltic. The Russo-Finnish treaty is the best news we have had since the war began and the narrowest escape from the frightful mistake of letting ourselves be dragged into class war on Russia, which is the dearest wish and insanest dream of our maddest old reactionaries.

Will Stalin penetrate further westwards now that he has the key to the West?

Why should he? Do you think he has not enough on his hands as it is? All he has done in Finland now that it is at his mercy is to secure the key of his front door. If the Nazi Reich or the British Empire had been in his place they would have annexed all Finland and probably forced their way into Norway as far as Narvik. But you cannot convince Imperialists that Communists are not just like themselves.

Will war spread now?

Well, as the first serious attempt to spread it has just failed, let us hope for the best: that is, for the triumph of wholesome funk and common humanity.

Do you see a possibility of stopping the war without 'giving in' and would it only mean a German victory?

Both sides will have to 'give in' very ingloriously if common sense does not stop the war first. What good would a victory do either way? We won one in 1918. It ended in the enemy winning the peace. 